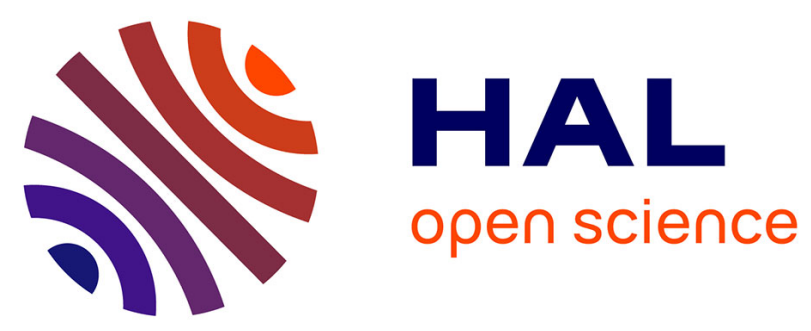

\title{
In memoriam Jamshid Darvish
}

Christiane Denys, François Bonhomme, Boris Kryštufek, Marjan Mashkour, Jean Denis Vigne, Roohollah Siahsarvie

\section{To cite this version:}

Christiane Denys, François Bonhomme, Boris Kryštufek, Marjan Mashkour, Jean Denis Vigne, et al.. In memoriam Jamshid Darvish. Mammalia, 2018, 82 (6), pp.521-528. 10.1515/mammalia-2018-0124 . hal-02406853

\section{HAL Id: hal-02406853 \\ https://hal.science/hal-02406853}

Submitted on 12 Dec 2019

HAL is a multi-disciplinary open access archive for the deposit and dissemination of scientific research documents, whether they are published or not. The documents may come from teaching and research institutions in France or abroad, or from public or private research centers.
L'archive ouverte pluridisciplinaire HAL, est destinée au dépôt et à la diffusion de documents scientifiques de niveau recherche, publiés ou non, émanant des établissements d'enseignement et de recherche français ou étrangers, des laboratoires publics ou privés. 


\section{Obituary}

\section{Christiane Denys, François Bonhomme, Boris Kryštufek, Marjan Mashkour, Jean Denis Vigne and Roohollah Siahsarvie}

\section{In memoriam Jamshid Darvish}

https://doi.org/10.1515/mammalia-2018-0124

On November 15, 2017, the community of mammalogists lost one of its prominent figures. Professor Jamshid Darvish, formerly transliterated as Djamchide Darviche (Figure 1), who was already suffering from thyroid cancer for several years, suddenly passed away in the hospital after severe epistaxis followed by heart failure. We present here some testimonies about his personality, his major achievements, as well as his entire bibliography to highlight the important contributions he made to the field of zoology, paleontology and systematics for his country and abroad.

Jamshid Darvish was born on February 10, 1952, in Birjand (Iran). After graduating from high school, he went to Tabriz in northwest Iran where he studied Natural Science at Tabriz University. On receiving a national scholarship, he moved to France during 1974-1978 where, at the University of Montpellier II, he obtained certificates in Ecology and Geology, and obtained a Diplôme d'Etudes Approfondies followed by a $\mathrm{PhD}$ in Biosystematics and Evolution, under the guidance of Dr Jacques Michaux. At that time, Institut des Sciences de l'Evolution-Montpellier (ISE-M) was started by Professor Louis Thaler and Jamshid Darvish was one of the first students of this research laboratory to benefit from the beginnings of the evolutionary biology discipline in France that included a multidisciplinary approach. His thesis entitled "Approche morphologique et morphométrique de la biosystématique à la lumière de la génétique des populations. Application aux genres Mus et Apodemus" allowed him to become familiar with rodents and different tools in integrative taxonomy from molecules to morphology, both at the species and subspecies levels. Moreover, he was in contact with the ISE-M paleontologists and became interested in this discipline. One of the main results of his $\mathrm{PhD}$ was the first description of the very faint morphological characters that distinguish two otherwise poorly known sympatric mouse species (Darviche et al. 1979, Darviche and Orsini 1982). His academic career started with the position of Assistant Professor, 1978-1984, in the Biology Department of Tabriz University, where he was the head of the department during the last 4 years. Jamshid then returned to his hometown (Birjand) and was appointed as the president of the University of Birjand for nearly 4 years. In 1987, he continued his career as an Assistant Professor in the Biology Department of the Ferdowsi University of Mashhad, where he was promoted to the position of Associate Professor in 1994 and a Full Professor in 1999. In his personal page (http://www.um.ac.ir/ darvish/), Jamshid Darvish has included three key words concerning his main topics of research: Rodents, Biosystematics, Evolution. In these areas, we can find a prolific scientific production, not only from his own work, but also from his Masters and $\mathrm{PhD}$ students. His bibliography lists more than 150 articles published in the fields of systematics, evolution, paleontology and archeozoology of rodents and other small mammals (see the References section). Among the most cited articles he published, one can find at least three articles about the evolution of the genus Mus and also a synthesis about the diversity of rodents in Iran. His invaluable contribution to the knowledge of the diversity of his country is also reflected through the description of a new species of three-toed jerboa (Jaculus thaleri Darvish and Hosseinie 2006) named after Louis Thaler from the ISE-M. Jamshid also contributed to the update of the faunal lists of Iran by adding new records of poorly known species like Golunda ellioti Gray, 1837 (Darvish et al. 2012a), the pygmy field mouse Apodemus uralensis (Pallas, 1811) (Darvish et al. 2010a), the Zarundny's jird (Meriones zarudnyi Heptner, 1937) (Darvish et al. 2010b), the Hotson's five-toed jerboa Allactaga hotsoni Thomas, 1920 (Darvish et al. 2006a) and the Euphrates jerboa Allactaga euphratica Thomas, 1881 (Darvish et al. 2012b). He made different taxonomic revisions using morphology and morphometrics as well as phylogenetic analyses like, for instance, revisions of the whole genus Meriones (Darvish 2009, 2011) or of the Iranian Apodemus (Darvish et al. 2015). Each of his students has co-authored between three and four papers with him, and various molecular phylogenetic and phylogeographic analyses of Iranian rodents have been published under his supervision. Among the latter, one can quote the study of Microtus phylogeny by Mahmoudi et al. (2017b,c,d), study of Apodemus (Shad et al. 2016), the analysis of Allactaga evolution as well as phylogeography of Meriones persicus (Dianat et al. 2010, 2013, 2016a,b), the phylogeny of Calomyscus by Shahabi et al. (2011, 2013a,b). 


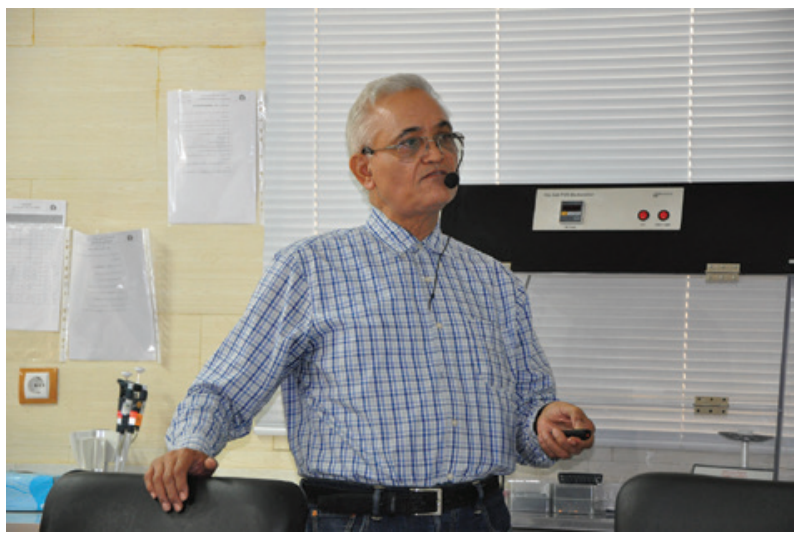

Figure 1: Jamshid Darvish at the Research Center for Emerging and Reemerging Infectious Diseases (Pasteur Institute Iran), Akanlu, Hamadan, Iran (May 2016).

Jamshid Darvish's interest in morphometric tools was never-ending and led to publications on skull geometric morphometrics in different rodents of Iran, particularly in Mus (Shabani et al. 2014, Siahsarvie et al. 2012), Apodemus (Siahsarvie and Darvish 2008), Microtus (Siahsarvie et al. 2013), Allactaga (Tarahomi et al. 2010) and Calomyscus (Zarei et al. 2013). He also published articles along with herpetologists and ornithologists as well as with entomologists. More recently he was developing collaborations on rodent zoonoses like leptospirosis (Esfandiari et al. 2016), plague and tularemia (Mostafavi et al. 2017) as well as in epidemiology (Esfandiari et al. 2015, 2017).

Jamshid Darvish was the first to formally introduce Biosystematics and Evolution as an educationary discipline in the universities of Iran. His determination for achieving high standards of international systematic research led him to become the founder of the Laboratory of Animals Center in Tabriz University, the founder and the director of Birjand station of the International Desert Research Center, the founder and director of Biosystematics Laboratory, Rodentology Research Department, and Institute of Applied Zoology, Rodent Study Group at the Ferdowsi University of Mashhad. Finally, he took the initiative of establishing the Natural History Museum of Khorassan which is still under construction at the Ferdowsi University of Mashhad. Besides this, Jamshid was the founder, director and the editor-in-chief of the "Iranian Journal of Animal Biosystematics" (published quarterly in English) and also the chief editor of the "Journal of Animal Research" (published quarterly in Persian). Jamshid gave lectures on Evolution, Taxonomy, Vertebrate Zoology, Mammalogy, as well as on Species and Speciation, Phylogenetic Systematics, Biosystematics, Field and Laboratory Methods in Biosystematics and

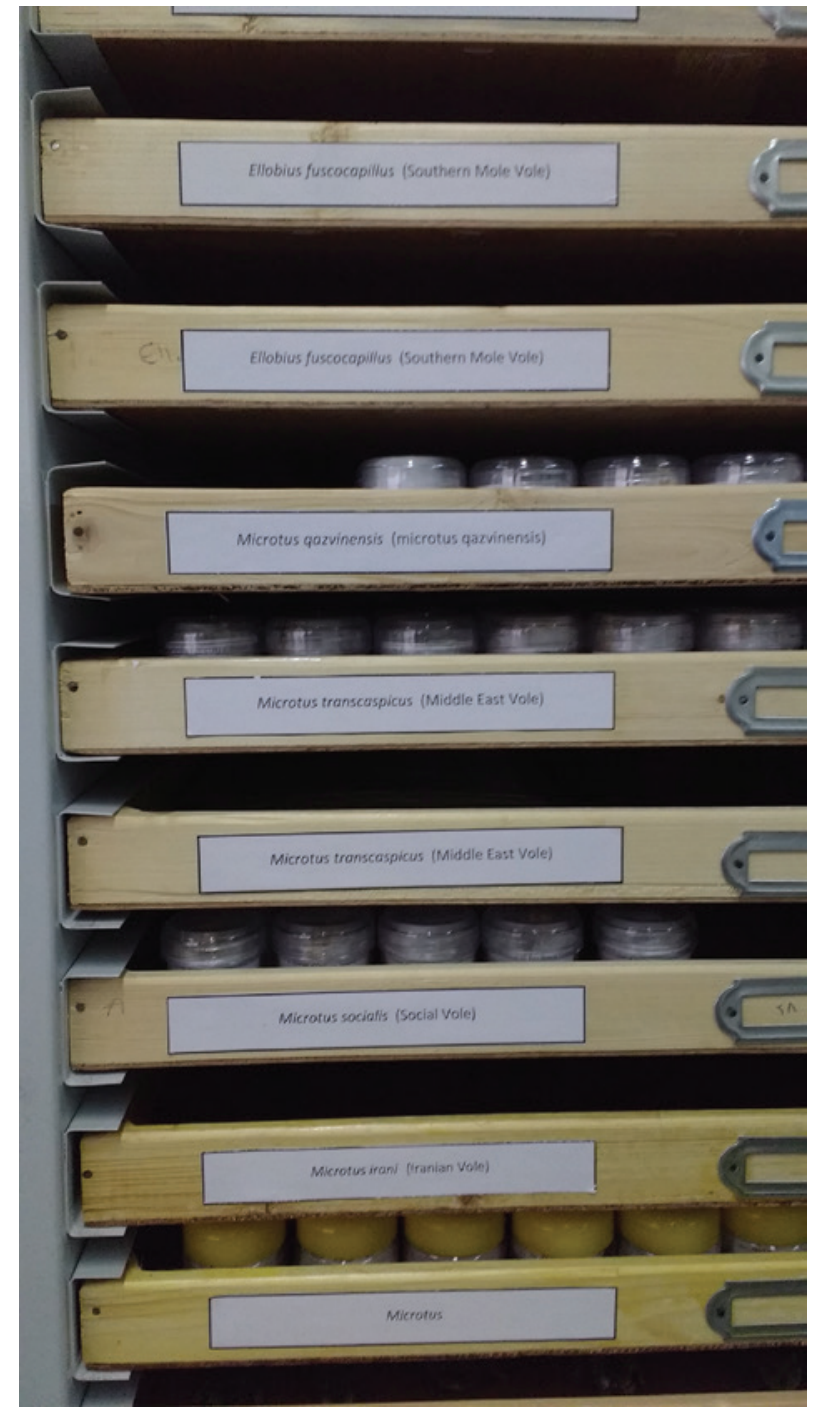

Figure 2: Darvish rodent collection at the Ferdowsi University of Mashhad.

Cabinets with skulls of Iranian species of jirds (Meriones).

Animal Contemporary Classification to undergraduate and postgraduate students.

During his entire scientific career, Jamshid Darvish had been involved in extensive fieldwork and collected an impressive amount of specimens which are now available to students and public in the Zoology collection at the Ferdowsi University of Mashhad, recently renamed as "Darvish Rodent Collection" in his honor (Figures 2 and 3).

Because Jamshid realized that young scientists in Iran need to get access to the literature of Evolutionary Biology, he translated several books from French or English to Persian among which one should mention the book by Charles Devillers (1973) (Introduction à l'étude systematique des vertébrés. Doin, Paris France), Ernst Mayr (1970) founding book (Populations, Species and Evolution. 


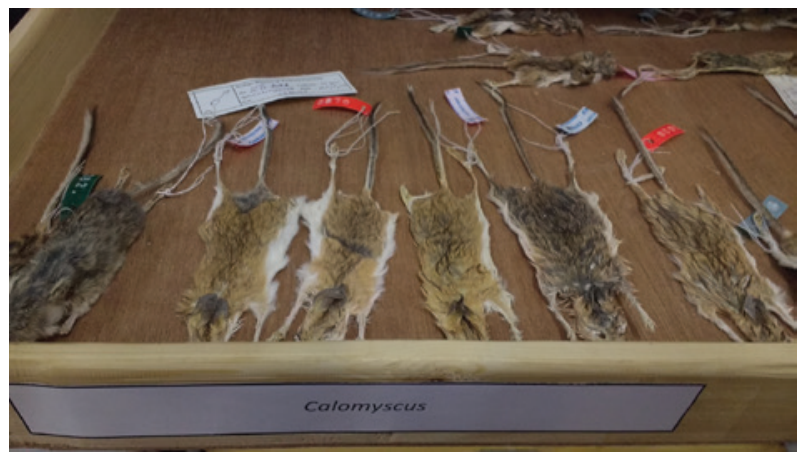

Figure 3: Darvish rodent collection at the Ferdowsi University of Mashhad.

A drawer containing skins of Iranian mouse-like hamsters (Calomyscus).

Harvard University Press), Ernst Mayr and Peter D. Ashlock (1991) (Principles of Systematic Zoology. McGraw-Hill College), Xavier Misonne (1959) (Zoogéographie des mammifères de l'Iran. Royal Belgian Institute of Natural Sciences) and the recent one by Cleveland P Hickman, Jr. et al. (2013) (Integrated principles of Zoology). He has also authored several books, among which "Methodologies in Animal Biosystematics" (Ferdowsi University Press, in Persian) was honored as the Best Scientific Book of Iran in 2014. Jamshid Darvish has supervised numerous Masters and $\mathrm{PhD}$ students and enjoyed the reputation of being an outstanding mentor. He was honored with the title of National Distinguished Professor in 2008.

Along with his numerous academic duties, Prof. Darvish was always inclined toward the general organization and management of the University and contributed to the development of Biological Science at various universities. He was the head of the Biology Department at the Tabriz University from 1980 to 1984 and then the President of Birjand University from 1984 to 1987. He was also one of the founders of the Birjand Branch of Azad University in 1981. In Mashhad he also accepted responsibilities as the Vice-Dean for Educational Affairs at the Faculty of Science from 1990 to 1994; Chairman of the Biology Department, Ferdowsi University of Mashhad 1995-1997; Vice-Dean for Research Affairs at the Faculty of Science from 1997 to 2002 and Manager of Research Affairs at the Ferdowsi University of Mashhad from 2002 to 2004.

We all knew him personally for different reasons. First in Montpellier he was well integrated into the student's band of Prof. Louis Thaler. He was a friendly and very good fellow but was always assuming a status of oriental person lost in an occidental world. He always kept his relationship with Montpellier and especially with the group of François Bonhomme, Janice Britton-Davidian and Pierre Boursot intact and stayed there during his sabbatical year in 2004. He also knew Dr. Francis Petter and the Zoology Mammal and Bird department collections of the Museum national d'Histoire naturelle (MNHN, Paris) very well. He especially revised the gerbilline and dipodid rodents of this collection for which he came for taxonomic revisions and stayed for 3 months in 2001 and during numerous visits to France. He also contributed to the field of archeozoology by aiding in the identification of several fossil specimens found in prehistoric Iranian and Central Asian archeological sites. As another example of Prof. Darvish's fidelity toward his French and other international collaborators, he sent joint $\mathrm{PhD}$ students to be trained at the Montpellier University, the MNHN of Paris, Natural History Museum of Slovenia, Russian Academy of Science, Ghent University and the University of Gothenburg.

These collaborations were also effective in the organization of different meetings and international conferences. For instance he organized, among others in 2001, the first conference entitled Applications of Biosystematics Studies on Rodents of Iran in the Ferdowsi University of Mashhad, Iran.

The last conference entitled "International conference on Integrative Approaches of Rodent studies" was held from 27th January to 1st February 2018 and gathered delegates from 15 countries. He was the one who initiated its organization and laid the basis for its effective realization. His life, however, did not last long enough to be with us during the days of the conference.

Jamshid Darvish was deeply convinced about the importance of biosystematics as a promising field as well as of evolutionary studies for which he was a precursor and developer in Iran. He was always keen of developing culture and education in his country and organized the first seminar in 1988 entitled "Analysing the obstacles and effective factors in cultural, educational development of Sistan-Baluchistan and Southern Khorasan regions" at the University of Birjand. We will always remember him as a very respectful, motivated, charismatic and affable person and we will deeply miss him.

\section{References}

Abdollahpour, G., M.R. Shirzadi, J. Darvish, Z. Mohammadi and M. Yazdani. 2016. Serological survey of leptospirosis in rodents of North Khorasan Province, Northeast of Iran. J. North Khorasan Univ. Med. Sci. 7: 725-733.

Akbarirad, S., R. Jalal, J. Darvish and M.M. Matin. 2009. Identification of three Iranian species of the genus Rattus (Rodentia, 
Muridae) using a PCR-RFLP technique on mitochondrial DNA. Hystrix It. J. Mamm 20: 69-77.

Akbarirad, S., J. Darvish and M. Aliabadian. 2016a. Molecular, chromosomal and morphometric variation in Calomyscus hotsoni and C. elburzensis (Calomyscidae, Rodentia) in the east of Iran. Folia Zool. 65: 27-37.

Akbarirad, S., J. Darvish and M. Aliabadian. 2016b. Phylogeography of Calomyscus elburzensis (Calomyscidae, Rodentia) around the Central Iranian Desert with description of a new subspecies in center of Iran. J. Sci. I. R. Iran 27: 5-21.

Akbarirad, S., J. Darvish and M. Aliabadian. 2016c. Increased species diversity of brush-tailed mice, genus Calomyscus (Calomyscidae, Rodentia), in the Zagros Mountains, western Iran. Mammalia 80: 549-562.

Akbarirad, S., J. Darvish, M. Aliabadian, and C.W. Kilpatrick. 2016d. Biosystematic study of Calomyscus mystax (Rodentia, Calomyscidae) from northeastern Iran. J. Anim. Biosystemat. 11: 65-77.

Akmali, V., A. Farazmand, J. Darvish and M. Sharifi. 2011. Phylogeography and taxonomic status of the greater mouse-tailed bat Rhinopoma microphyllum (Chiroptera: Rhinopomatidae) in Iran. Acta Chiropterol. 13: 279-290.

Aliabadian, M., N.A. Kakhky and J. Darvish. 2012. Phylogenetic systematics of Barn Owl (Tyto alba (Scopoli, 1769)) complex inferred from mitochondrial rDNA (16S rRNA) taxonomic implication. Taxon. Biosystem. J. 4: 1-12.

Aliabadian, M., J. Darvish, F. Yazdani Moghaddam and S. Mohammadi. 2013. Geometric morphometric analyses of the shorttailed Bandicoot Rat (Nesokia indica) (Rodentia: Muridae) in the north and southeast of Iran. Zool. Ecol. 23: 260-265.

Ameri, M. and J. Darvish. 2008. Taxonomic study of 6 Iranian Meriones species (Muridae, Rodentia). Iran. J. Biol. 21: 630-643.

Amir Afzali, Y., J. Darvish and F. Yazdani Moghadam. 2017. Study of rodents' fauna of the Jiroft and Anbarabad townships in southeast of Iran. Iran. J. Anim. Biosystemat. 13: 119-129.

Arzamani, K., G. Abdollahpour, M.R. Shirzadi and J. Darvish. 2015. Serological survey of Leptospirosis in rodents of North Khorasan Province, Northeast of Iran. J. North Khorasan Univ. Med. Sci. 7: 725-733.

Arzamani, K., M. Salehi, I. Mobedi, A. Adinezade, H. Hasanpour, M. Alavinia, J. Darvish, M.R. Shirzadi and Z. Mohammadi. 2017. Intestinal helminths in different species of rodents in north Khorasan province, northeast of Iran. Iran. J. Parasit. 12: 267-273.

Ashrafzadeh, M.R., M. Karami and J. Darvish. 2007. A study on morphology and morphometry of subfamily of Gerbillinae (Rodentia: Muridae) in Geno Biosphere Reserve, Hormozgan Province. Iran. J. Biol. 20: 110-120.

Ashrafzadeh, M.R., M. Karami and J. Darvish. 2008. Comparison of suitability of live traps in rodents sampling (case study: Geno Protected Area, Hormozgan Province). Iran. J. Biol. 21: 493-500.

Ashrafzadeh, M.R., M. Karami and J. Darvish. 2010a. A study on the correlation of diversity and abundance of rodents with the vegetation and elevation in Geno Biosphere Reserve, Hormozgan Province. J. Nat. Environ. 63: 1-13.

Ashrafzadeh, M.R., M. Karami, J. Darvish, T. Shahi and T. Ghadirian. 2010b. A study of intraspecies variations of Baluchistan gerbil, Gerbillus nanus Blanford, 1875 (Rodentia\&58; Muridae) in Hormozgan Province, Iran. Taxon. Biosystem. J. 2: 11-24.
Ashrafzadeh, M.R., M. Karami and J. Darvish. 2011. Intraspecific variations within Tatera indica Hardwicke. 1807 (Muridae, Rodentia) populations in Hormozgan province, Iran. J. Nat. Environ. 64: 347-361.

Azarpira, M., S.M. Madjidzadeh and J. Darvish. 2012. A faunistic study of rodents (Mammalia: Rodentia) in Anjerk prohibited hunting area, Kerman province. Iran. J. Biol. 25: 240-251.

Bagherian, A., J. Darvish and N.A. Rastgar Pouyani. 2007. Cladistic study of Muridae rodents (Mammalia: Rodentia) from the east of Iran. Iran. J. Biol. 20: 269-276.

Barani-Beiranvand, H., M. Aliabadian, Irestedt, Y. Qu, J. Darvish, T. Székely, R.E. van Dijk and P.G.P. Ericson. 2017. Phylogeny of penduline tits inferred from mitochondrial and microsatellite genotyping. J. Avian Biol. 48: 932-940.

Beiromvand, M., L. Akhlaghi, S.H.F. Massom, A.R. Meamar, J. Darvish and E. Razmjou. 2013. Molecular identification of Echinococcus multilocularis infection in small mammals from northeast Iran. PLoS Negl. Trop. Dis. 7: e2313.

Biglari, F., M. Javeri, M. Mashkour, Y. Yazdi, S. Shidrang, M. Tengberg, K. Taheri and J. Darvish. 2009. Test excavations at the Middle Paleolithic sites of Qaleh Bozi, southwest of Central Iran: A preliminary report. In: (M. Otte, F. Biglari and J. Jaubert, eds.) Iran Palaeolithic. Proceedings of the XV World Congress UISPP, Lisbonne, Vol. 28, BAR International Series 1968, pp. 29-38.

Bonhomme, F., R. Anand, D. Darviche, W. Din and P. Boursot. 1994. The house mouse as a ring species? In: (K. Moriwaki, T. Shiroishi and H. Yonekowa, eds.) Genetics in Wild Mice: Its application in biomedical research. Japan Scientific Societies Press, Tokyo. pp. 13-23.

Boursot, P., W. Din, R. Anand, J. Darviche, B. Dod, F. Von Deimling, G.P. Talwar and F. Bonhomme. 1996. Origin and radiation of house mouse: mitochondrial DNA phylogeny. J. Evol. Biol. 9: 391-415.

Cucchi, T., Z.E. Kovács, R. Berthon, A. Orth, F. Bonhomme, A. Evin, R. Siahsarvie, J. Darvish, V. Bakhshaliyev and C. Marro. 2013. On the trail of Neolithic mice and men towards Transcaucasia: zooarchaeological clues from Nakhichevan (Azerbaijan). Biol. J. Linn. Soc. 108: 917-928.

Darviche, D. and P. Orsini. 1982. Critère de différentiation morphologique et biométrie de deux espèces de souris sympatriques: Mus spretus et Mus musculus domesticus. Mammalia 46: 205-217.

Darviche, J., F. Benmehdi, J. Britton-Davidian and L. Thaler. 1979. Données préliminaires sur la systématique biochimique des genres Mus et Apodemus en Iran. Mammalia 43: 427-429.

Darvish, J. 1988. Discrimination of different subspecies of house mouse Mus musculus from Eurasia and North Africa on the basis of their morphometric characteristics. Iran. J. Biol. 7: 49-71 (in Persian).

Darvish, J. 1992. Preliminary study of the fauna of rodents in the Northern Khorassan with the aid of pellets from the prey birds. Applied Entomology and Phytopathology. Plant Pest Dis. Res. Inst. 59 (in Persian).

Darvish, J. 1995a. Presence of two sympatric species of Mus musculus L.1766 and Mus macedonicus P \& R 1983 (Muridae, Rodentia) in Qazvin region Iran. J. Sci. Univ. Tehran 21 (in Persian)

Darvish, J. 1995b. Identification of subspecies of Mus musculus L. 1766 (Muridae, Rodentia) of Khorasan province by multivariate analysis. Applied Entomology Phytopathology. Plant Pest Dis. Res. Inst. 62 (in Persian). 
Darvish, J. 1997. Morphological studies of dentary and skull of house mouse ( $M$. musculus L.) from Eurasia and North Africa. Iran. J. Biol. 4: 84-110 (in Persian).

Darvish, J. 1998. Discrimination of different subspecies of mouse Mus musculus from Eurasia and North Africa on the basis of their morphmetric characteristics. Iran. J. Biol. 7 (in Persian).

Darvish, J. 2004. Analysis of morphological variation of molars teeth of house mouse Mus musculus 1766 of Eastern Iranian and their relative oldness in comparison with Mediterranean basin house mouse. Iran. J. Biol. 16: 13-19 (in Persian).

Darvish, J. 2008. Biosystematics approach to geographic variations of house mouse group, Mus musculus L. 1766. Iran. J. Anim. Biosystemat. 4: 31-54.

Darvish, J. 2009. Morphometrical comparison of fourteen species of the genus Meriones Illiger, 1811 (Gerbillinae, Rodentia) from Asia and North Africa. Iran. J. Anim. Biosystemat. 5: 59-77.

Darvish, J. 2011. Morphological comparison of fourteen species of the genus Meriones Illiger, 1811 (Gerbillinae, Rodentia) from Asia and North Africa. Iran. J. Anim. Biosystemat. 7: 49-74.

Darvish, J. and F. Hosseinie. 2005. New Species of Three-toed Jerboa Jaculus thaleri sp. nov (Dipodidae: Rodentia) from the Deserts of Khorasan Province, Iran. Iran. J. Anim. Biosystemat. 1: 21-27.

Darvish, J. and O. Mirshamsi. 1999. Identification and study of Black Widow Spider Latrodectus teredecimguttatus in Khorasan Province. Biaban 3 (in Persian).

Darvish, J. and E. Rastegar-Pouyan. 2012. Biodiversity conservation of reptiles and mammals in the Khorasan provinces, northeast of Iran. Prog. Biol. Sci. 2: 95-109.

Darvish, J., A.R. Ghiyasi and M. Khosravi. 1999. Recognition of rodents of Robat-Sharaf Pellets Owl, by morphological and neontological studies. Science (As-Zahra) 70 (in Persian).

Darvish, J., R. Siahsarvie, M. Javidkar and O. Mirshamsi. 2005. New records of snow vole Chionomys nivalis (Rodentia: Arvicolinae) from the Binaloud and Elburz mountains of Iran. Acta Zool. Cracov. 48A: 60-70.

Darvish, J., O. Mirshamsi Khaki, R. Siahsarvie and M. Javidkar. 2006a. New records of Hotson's Jerboa Allactaga hotsoni from Khorasan and Yazd provinces. I. R. Iran J. Sci. 17: 303-307.

Darvish, J., A. Orth and F. Bonhomme. 2006b. Genetic transition in the house mouse, Mus musculus of Eastern Iranian Plateau. Folia Zool. 55: 349-357.

Darvish, J., R. Siahsarvie, O. Mirshamsi, N. Kayvanfar, N. Hashemi and F. Sadeghie Shakib. 2006c. Diversity of the rodents of northeastern Iran. Iran. J. Anim. Biosystemat. 2: 57-76.

Darvish, J., T. Hajjar, M.M. Moghaddam, F. Hadad and S. Akbari Rad. 2008. New species of five-toed jerboa (Rodentia: Dipodidae, Allactaginae) from northeast Iran. J. Sci. I. R. Iran 19: 103-109.

Darvish, J., S. Akbary Rad, R. Siahsarvieh, M.A. Hossein Pour Feizi and F. Ghorbani. 2010a. New record on pigmy field mouse (Muridae, Rodentia) from Northeast Iran. Hystrix It. J. Mamm. 21: 115-126.

Darvish, J., K. Hamidi Loyen and A. Mahmoudi. 2010b. First record of Zarudny's Jird, Meriones zarudnyi Heptner, 1937 (Rodentia: Muridae) in Shirvan, Northeast Iran. Iran. J. Anim. Biosystemat. 6: 67-68.

Darvish, J., Y. Amirafzali and K. Hamidi. 2012a. Further record of Golunda ellioti Gray, 1837 from South East of Iran with notes on its postcranial skeleton. Iran. J. Anim. Biosystemat. 8: 79-82.

Darvish, J., M. Tarahomi, S. Akbarirad and M. Dianat. 2012b. A new record of Allactaga euphratica from Ilam province, West of Iran. Iran. J. Anim. Biosystemat. 8: 75-77.
Darvish, J., M. Javidkar and R. Siahsarvie. R. 2013. A new species of wood mouse of the genus Apodemus (Rodentia, Muridae) from Iran. Zool. Middle East 38: 5-16.

Darvish, J., Z. Mohammadi, F. Ghorbani and E. Mostafavi. 2014 a. Morphological morphometric characterisation of the eastern broadtoothed field mouse Apodemus mystacinus (Rodentia: Muridae) from Zagros Mountains, north-western Iran. Acta Zool. Bulg. 66: 461-468.

Darvish, J., Z. Mohammadi, A. Mahmoudi and R. Siahsarvie. 2014b. Faunistic and taxonomic study of Rodents from northwestern Iran. Iran. J. Anim. Biosystemat. 10: 119-136.

Darvish, J., Z. Mohammadi, F. Ghorbani, A. Mahmoudi and S. Dubey. 2015. Phylogenetic relationships of Apodemus Kaup, 1829 (Rodentia: Muridae) species in the Eastern Mediterranean inferred from mitochondrial DNA, with emphasis on Iranian Species. J. Mamm. Evol. 22: 583-595.

Darvish, J., K. Arzamani, G. Abdolahpoor and M.R. Shirzadi. 2016a. Rodent leptospirosis in North Khorasan Province, northeast of Iran. Int. J. Infect. Dis. 45: 465.

Darvish, J., M. Tarahomi, M. Dianat, Z. Mohammadi, H. Haddadian Shad and S. Moshtaghi. 2016b. Biosystematics of three-toed Jerboas, genus Jaculus (Erxleben, 1777) (Dipodidae, Rodentia) from Iran. Iran. J. Anim. Biosystemat. 12: 123-139.

Dianat, M., M. Tarahomi, J. Darvish and A. Aliabadian. 2010. Phylogenetic analysis of the five-toed Jerboa (Rodentia) from the Iranian Plateau based on mtDNA and morphometric data. Iran. J. Anim. Biosystemat. 6: 49-59.

Dianat, M., M. Aliabadian, J. Darvish and S. Akbarirad. 2013. Molecular phylogeny of the Iranian Plateau five-toed jerboa, Allactaga (Dipodidea: Rodentia), inferred from mtDNA. Mammalia 77: 95-103.

Dianat, M., J. Darvish, M. Aliabadiana, H. Haddadian, A. Khajeh and V. Nicolas. 2016a. Integrative taxonomy of Meriones persicus (Rodentia, Gerbillinae) in Iran. Iran. J. Anim. Biosystemat. 12: 77-95.

Dianat, M., J. Darvish, R. Cornette, M. Aliabadian and V. Nicolas. 2016b. Evolutionary history of the Persian Jird, Meriones persicus, based on genetics, species distribution modelling and morphometric data. J. Zool. Syst. Evol. Res. 55: 29-45.

Din, W., R. Anad, P. Boursot, J. Darviche, B. Dod, E. Jouvin-Marche, A. Orth, G.P. Talwar, P.A. Cazenave and F. Bonhomme. 1996. Origin and radiation of the house mouse: clues from nuclear genes. J. Evol. Biol. 9: 519-539.

Esfandiari, B., M.R. Pourshafie, M.M. Gouya, P. Khaki, R. Mostafavi, J. Darvish, S.M. Bidhendi, H. Hanifi and H. Nahrevanian. 2015. An epidemiological comparative study on diagnosis of rodent leptospirosis in Mazandaran Province, northern Iran. Epidemiol. Health 37: e2015012.

Esfandiari, B., H. Nahrevanian, M.R. Pourshafie, M.M., Gouya, P. Khaki, E. Mostafavi, J. Darvish, S.M. Bidhendi, H. Hanifi and M. Gharakhani. 2016. Association of prevalent Leptospira species with different rodents of three northern provinces in Iran using microscopic agglutination test. Adv. Stud. Biol. 8: 53-63.

Esfandiari, B., H. Nahrevanian, M.R. Pourshafie, M.M. Gouya, P. Khaki, E. Mostafavi, J. Darvish and H. Hanifi. 2017. Epidemiological distribution of rodents as potent reservoirs for infectious diseases in the provinces of Mazandaran, Gilan and Golestan, northern Iran. Infect. Dis. Rep. 9: 6900/62-65.

Eskandarzadeh, N., J. Darvish, E.R. Pouyani and F. Ghassemzadeh. 2013. Reevaluation of the taxonomic status of sand boas of the 
genus Eryx (Daudin, 1803) (Serpentes: Boidae) in northeastern Iran. Tr. J. Zool. 37: 348-356.

Esmaeili, R.S., J. Darvish, F. Hadad and F. Ghasemzade. 2008. A new karyotype of Calomyscus from the Khorasan Province, Iran. Hystrix Ital. J. Mamm. 19: 67-71.

Fakharzadeh, F., J. Darvish, Z. Ghassemzadeh and H.G. Kami. 2009. Anuran karyological study of Khorasan province. Asian J. Biol. Sci. 2: 66-73.

Fakharzaeh, F., J. Darvish, H.G. Kami, F. Ghasemzadeh and E. Rastegar-Pouyani. 2014. New karyological and morphometric data on poorly known Bufo surdus and Bufo luristanicus in comparison with data of diploid green toads of the Bufo viridis complex from South of Iran. Asian Herp. Res. 5: 169-178.

Fakharzadeh, F, J. Darvish, H.G. Kami, F. Ghassemzadeh, E. Rastegar Pouyani and M. Stöck. 2015. Discovery of triploidy in Palearctic green toads (Anura: Bufonidae) from Iran with indications for a reproductive system involving diploids and triploids. Zool. Anz. 255: 25-31.

Gholamhosseini, A., M. Aliabadian, J. Darvish, T. Topfer and G.-P. Sætre. 2017. An expanding hybrid zone between Black-headed and Red-headed Buntings in northern Iran. Ardea 105: 27-36.

Ghorbani, F., J. Darvish and O. Mirshamsi. 2010. Rodent fauna of the western Golestan Province in northeast Iran. Iran. J. Anim. Biosystemat. 6: 36-48.

Ghorbani, F., Z. Mohammadi, J. Darvish and M. Aliabadian. 2014. Gradient of rodent species diversity across altitudes in Hyrcanian region, northeast Iran. Zool. Ecol. 24: 192-198.

Ghorbani, F., Z. Mohammadi, J. Darvish, H.G. Kami and R. Siahsarvie. 2015. Morphological and morphometric characterization of the new records of the East European vole (Microtus levis Miller, 1908) from northeast Iran. J. Asia-Pac. Biodivers. 8: 233-237.

Haddadian, H., J. Darvish and P. Rastegar. 2016. Different distributional patterns in some small mammals in the central Iran inferred from MtDna markers. Iran. J. Biol. 29: 411-425.

Hamid, H., J. Darvish, E. Rastegar-Pouyani and A. Mahmoudi. 2016. Subspecies differentiation of the house mouse Mus musculus Linnaeus, 1758 in the center and east of the Iranian plateau and Afghanistan. Mammalia 81: 147-168.

Hamidi, K., H. Mehraban and J. Darvish. 2013. Preliminary study of rodents' fauna (Mammalia; Rodentia) of Khaf township, southeast of Khorasan Razavi province, Iran, using pellets of birds of prey. Prog. Biol. Sci. 3: 86-89.

Hamidi, K., J. Darvish and M.M. Matin. 2016. New records of the William's Jerboa, Paralactaga cf. williamsi (Thomas, 1897) (Rodentia: Dipodidae) from northeastern Iran with notes on its ecology. Check List 12: 1855.

Hamidi, K., J. Darvish, M.M. Matin, A.S. Javanmard and C.W. Kilpatrick. 2017. Tooth morphogenesis and FGF4 expression during development of molar tooth in three muroid rodents: Calomyscus elburzensis (Calomyscidae), Mesocricetus auratus (Cricetidae) and Mus musculus (Muridae). Anat. Rec. 300: 2138-2149.

Hamidi Loyen, K., J. Darvish, M.M. Matin and V. Malikov. 2015. A field study on the behaviour of Calomyscus elburzensis Goodwin, 1938 (Rodentia: Calomyscidae): Sexual and seasonal variations in the trapping success. Acta Zool. Bulg. 67: 521-528.

Hamidi Loyen, K., J. Darvish and M.M. Matin. 2017. Ecological survey of two Calomyscidae species; Goodwin's brush-tailed mouse and Hotson's brush-tailed mouse (Rodentia) in the eastern parts of Iran. Acta Ecol. Sinica 37: 105-114.
Hardouin, E.A., A. Orth, M. Teschke, J. Darvish, D. Tautz and F. Bonhomme. 2015. Eurasian house mouse (Mus musculus L.) differentiation at microsatellite loci identifies the Iranian Plateau as a phylogeographic hotspot. BMC Evol. Biol. 15: 26.

Hashemi, N. and J. Darvish. 2008. The identification of a new mammal fossils fauna in Pleistocene sediments of eastern Iran and its comparison to Maragha Fauna. Geosciences 17: 108-115.

Hashemi, N., J. Darvish and M. Mashkour. 2007a. Preliminary study of Ellobius (Rodentia: Arvicolinae) in Kani Mikaeil Cave of Kurdistan Province, West of Iran. J. Sci. (University of Tehran) 32: 375-379.

Hashemi, N., J. Darvish, M. Mashkour and F. Biglari. 2007b. Rodents and lagomorphs remains from late Pleistocene and early Holocene Caves and Rochshelter sites in the Zagros region, Iran. Iran. J. Anim. Biosystemat. 2: 25-33.

Hezaveh, N., F. Ghasemzadeh and J. Darvish. 2008. Biosystematic study (morphology, karyology and morphometry) of anuran Amphibia in Markazy Province. Iran. J. Biol. 20: 458-467.

Hosseinpour Feizi, M., J. Darvish, N. Pouladi, S. Akbari Rad and R. Siahsarvie. 2009. Biosystematic study of steppe field mouse Apodemus witherbyi (Rodentia: Muridae) from North West Iran. Iran. J. Anim. Biosystemat. 5: 47-58.

Hosseinzadeh, M. and J. Darvish. 2013. Biosystematic study of great gerbil species Rhombomys opimus Lichtenstein, 1823 (Rodentia: Gerbillinae) in Iran. Iran. J. Biol. 26: 282-288.

Jangjoo, M., J. Darvish and J.D. Vigne. 2011. Application of outline analysis on fossil and modern specimens of Apodemus. Iran. J. Anim. Biosystemat. 7: 143-155.

Javidkar, M., J. Darvish and A. Riyahiye. 2006. Identification and new record of Hyrcanian Wood Mouse (Apodemus hyrcanicus) in Noor Region (Iran). J. Envir. Stud. 32: 69-74.

Javidkar, M., J. Darvish and A. Riahi Bakhtiari. 2007. Morphological and morphometric analyses of dental and cranial characters in Apodemus hyrcanicus and A. witherbyi (Rodentia: Muridae) from Iran. Mammalia 71: 56-62.

Javidkar, M., J. Darvish and A. Riahi Bakhtiari. 2013. Discriminant analysis of dental and cranial characteristics in the wood mice Apodemus hyrcanicus and $A$. hermonensis (Rodentia, Muridae) from Iran. Zool. Middle East 35: 5-12.

Karamii, M., R. Hutterer, P. Benda, R. Siahsarvie and B. Kryštufek. 2008. Annotated check-list of the mammals of Iran. Lynx, Series Nova 39: 63-102.

Kayvanfar, N., R. Siahsarvie and J. Darvish. 2011. A study on Rattus (Muridae, Rodentia) of Iran based on morphological, morphometrical and karyotypical research. Iran. J. Biol. 24: 717-727.

Khajeh, A., J. Darvish and G.H. Razmi. 2015. A contribution on rodent fauna of the Jaz Murian depression, southeast Iran. Biodivers. J. 7: 203-214.

Khajeh, A., G.H. Razmi and J. Darvish. 2017. A study of ectoparasites in wild rodents of the Jaz Murian area in the southeast of Iran. Asian Pac. J. Trop. Dis. 7: 418-421.

Khosravi, M. and J. Darvish. 1999. Biosystematics of genus Meriones in north Khorasan Province. J. Sci. Ferdowsi Univ. Mashhad 11 (in Persian).

Mahmoudi, A., J. Darvish and M. Aliabadian. 2014. The Karaman vole Microtus irani karamani is a new record for Iran (Arvicolinae; Microtus). Iran. J. Anim. Biosystemat. 10: 51-56.

Mahmoudi, A., J. Darvish, M. Aliabadian, M. Khosravi, F. Golenishchev and B. Kryštufek. 2014a. Chromosomal diversity in the genus Microtus at its southern distributional margin in Iran. Folia Zool. 63: 290-295. 
Mahmoudi, A., J. Darvish and M. Aliabadian. 2014b. Evaluating the taxonomic validity of molecular clades within tribe Arvicolini (Mammalia). Taxon. Biosystem. 6: 13-22.

Mahmoudi, A., J. Darvish and M. Aliabadian. 2015. Taxonomic identity of Microtus qazvinensis Golenishchev et al. 2003 (Rodentia, Arvicolinae) from the northwest of Iran. Mamm. Res. 60: 71-79.

Mahmoudi, A., B. Kryštufek, M. Aliabadian, F.Y. Moghaddam and J. Darvish. 2017a. All quiet in the East: molecular analysis retrieves Chionomys layi as part of $C$. nivalis. Folia Zool. 66: 67-71.

Mahmoudi, A., B. Kryštufek, J. Darvish, M. Aliabadian, F. Tabatabaei Yazdi, F.Y. Moghaddam and F. Janžekovič. 2017b. Craniometrics are not outdated: interspecific morphological divergence in cryptic arvicoline rodents from Iran. Zool. Anz. 270: 9-18.

Mahmoudi, A., J. Zima, B. Kryštufek, J. Darvish, M. Aliabadian and A. Arslan. 2017c. Systematic relationships within the Microtus arvalis (Rodentia: Cricetidae) group in Iran, inferred from cytogenetic analyses. Zool. Middle East 64: 1-8.

Mahmoudi, A., J. Darvish, M. Aliabadian, F.Y. Moghaddam and B. Kryštufek. 2017d. New insight into the cradle of the grey voles (subgenus Microtus) inferred from mitochondrial cytochrome b sequences. Mammalia 81: 583-593.

Mirshamsi, O., J. Darvish and H.R. Goodarzi. 2000. Identification and study of five genera of crab spiders in Khorasan Province (Araneidae, Thomicidae). J. Entomol. Soc. Iran 19: 15-30 (in Persian).

Mirshamsi, O., J. Darvish and N. Kayvanfar. 2007. A preliminary study on Indian Gerbils, Tatera indica Hardwicke, 1807 at population level in eastern and southern parts of Iran (Rodentia: Muridae). Iran. J. Anim. Biosystemat. 3: 49-61.

Moghaddam, F.Y., J. Darvish, N. Mahdavi, S. Hahri, A.S. Abdulamir and S. Khalija Daud. 2009a. Lectin histochemistry assay in colon tissues for inter-species characterization. Am. J. Bioch. Biotech. 5: 7-13.

Moghaddam, F.Y., J. Darvish, N. Mahdavi, S. Hahri, A.S. Abdulamir, M. Mousavi and S. Khalija. 2009b. Comparative histological and histochemical inter-species investigation of mammalian sub mandibular salivary glands. Res. J. App. Sci. 4: 50-56.

Mohammadi, Z., J. Darvish, F. Haddad and F. Ghorbani. 2012. A karyological study of some murid rodents (Rodentia: Muridae) of Iran. Prog. Biol. Sci. 2: 30-39.

Mohammadi, Z., J. Darvish, F. Ghorbani and F. Haddad. 2013. Cytogenetic characterization of 23 species of rodents from Iran. Iran. J. Anim. Biosystemat. 9: 57-72.

Mohammadi, Z., J. Darvish, F. Ghorbani and E. Mostafavi. 2014. First record of the Caucasus field mouse Apodemus ponticus Sviridenko, 1936 (Rodentia Muridae) from Iran. Biodivers. J. 5: 475-480.

Molavi, F., J. Darvish, F. Haddad and M.M. Matin. 2015a. Comparative cytogenetic analysis in the populations of house mouse group, Mus musculus L. 1766 (Cytotype $2 \mathrm{n}=40$ ) (Rodentia: Muridae) in Iran. J. Cell Mol. Res. 7: 133-142.

Molavi, F., J. Darvish, F. Haddad and M.M. Matin. 2015b. Chromosome C-banding in Mus musculus L.1766 strains shows a fixed position for the centromere and variable amounts in different populations. J. Gen. Res. 1: 83-88.

Molavi, F., J. Darvish, F. Haddad and M.M. Matin. 2016a. Variation of the centromeric heterochromatin region (CHR) in the Iranian house mouse Mus musculus Linnaeus, 1758 (Rodentia: Muridae). Caryologia 69: 249-255.

Molavi, F., J. Darvish, F. Haddad and M.M. Matin. 2016b. A new cytotype of the Iranian house mouse, Mus musculus Linnaeus, 1758
(Rodentia: Muridae), in Birjand region, eastern Iran: implications for the evolution of sex-autosome translocations. Iran. J. Anim. Biosystemat. 12: 111-122.

Momenzadeh, M., J. Darvish, F. Toutoniyan, M. Sarmad and F. Sadeghi Shakib. 2008. Investigation of climatic effects on the shape and volume of tympanic bulla of Meriones libycus and Meriones persicus (Muridae: Rodentia) from northeastern Iran: an evolutionary approach. Iran. J. Anim. Biosystemat. 4: 63-73.

Momtazi, F., J. Darvish, F. Ghassemzadeh and A. Moghimi. 2008. Elliptic Fourier analysis on the tympanic bullae in three Meriones species (Rodentia, Mammalia): its application in biosystematics. Acta Zool. Cracov. A 51: 49-58.

Momtazi, F., F. Ghassemzadeh, J. Darvish and R. Zarei. 2010. The study of morphology and anatomy of tympanic bullae in the genus Meriones and its adaptation role using histological techniques and electronical microscope. Iran. J. Biol. 23: 259-266.

Moshtaghi, S., J. Darvish, O. Mirshamsi and A. Mahmoudi. 2016. Cryptic species diversity in the genus Allactaga (Rodentia: Dipodidae) at the edge of its distribution range. Folia Zool. 65: 142-147.

Mostafavi, E., A.H. Shahraki, A. Japoni-Nejad, S. Esmaeili, J. Darvish, M.M. Sedaghat, A. Mohammadi, Z. Mohammadi, A. Mahmoudi, B. Pourhossein, A. Ghasemi, M. Gyuranecz and E. Carniel. 2017. A field study of plague and Tularemia in rodents, Western Iran. Vector-Borne Zoonotic Dis. 17: 247-253.

Naseri, Z., R. Jalal and J. Darvish. 2006a. Genetic study on Apodemus avicennicus and Apodemus witherbyi by RAPD-PCR. Iran. J. Anim. Biosystemat. 2: 77-81.

Naseri, Z., R. Jalal, J. Darvish and M. Farsi. 2006b. Determination of Meriones species (Rodentia Gerbillinae) by RAPD-PCR. Iran. J. Anim. Biosystemat. 2: 35-40.

Nasr, A., J. Darvish, P. Rastgar and H. Ejtehadi. 2008. Survey of lizard fauna of Salehabad of Torbat-E-Jam, Razavi Khorasan Province. Iran. J. Biol. 21: 361-368.

Otte, M., F. Biglari, D. Flas, S. Shidrang, N. Zwyns, M. Mashkour, R. Naderi, A. Mohaseb, N. Hashemi, J. Darvish and V. Radu. 2007. The Aurignacian in the Zagros region: new research at Yafteh cave, Lorestan, Iran. Antiquity 81: 82-96.

Rajabi-Maham, H., A. Orth, R. Siahsarvie, P. Boursot, J. Darvish and F. Bonhomme. 2012. The south-eastern house mouse Mus musculus castaneus (Rodentia: Muridae) is a polytypic subspecies. Biol. J. Linn. Soc. 107: 295-306.

Rastegar-Pouyani, E., N. Eskandarzadeh and J. Darvish. 2014. Reevaluation of the taxonomic status of sand boas of the genus Eryx (Daudin, 1803) (Serpentes: Boidae) in north-eastern Iran using sequences of the mitochondrial genome. Zoo. Middle East 60: 320-326.

Saeedzadeh, S., A. Mehdipour, J. Darvish, M. Aliabadian and A. Mahmoudi. 2017. New look to the con-specificity of the two shrews, Crocidura gmelini and C. suaveolens from Iran; geometric morphometric approach. Iran. J. Anim. Biosystemat. 13: 237-246.

Sahebjam, B., J. Darvish, E. Rastegar-Pouyani, R. Siahsarvie and S. Akbarirad. 2010. A preliminary molecular study of the Iranian species of Calomyscus (Rodentia-Calomyscidae) using RFLP. Iran. J. Anim. Biosystemat. 5: 33-41.

Seidmousavi, F., J. Darvish and M. Aliabadian. 2001. Biosystematics of Rattus turkestanicus (Rodentia) of Mashhad region. Applied Enthomology and phytopathology. Plant Pests Dis. Res. Inst. 68: (1 and 2) (in Persian). 
Sepahi, S., R. Jalal, B. Toluinia, A. Asoodeh and J. Darvish. 2013. Evaluation of relationship between HNF-1 $\alpha$ and GLP-1R polymorphisms and type 2 diabetes in a population living in northeast of Iran. J. Cell Mol. Res. 5: 54-59.

Shabani, M., J. Darvish, M. Mashkour, F. Ghasemzadeh and O. Mirshamsi. 2010. Contemporary and sub-fossil house mice (Mus musculus Linnaeus, 1758) (Rodentia: Muridae) from Iran. Iran. J. Anim. Biosystemat. 6: 45-54.

Shabani, M., F. Ghassemzadeh and J. Darvish. 2014. Geometric morphometric analysis of the molars in three species of the genus Mus (Mus) (Rodentia, Muridae) based on the outline method. Egypt. J. Biol. 16: 24-28.

Shad, H.H., J. Darvish, T. Mohammadian, A. Mahmoudi, N.A. Kakhki, M. Ghanbarifardi, F. Molavi and H. Barani-Beiranvand. 2014. Preliminary study of rodents using pellets of predatory birds in Iran. Iran. J. Anim. Biosystemat. 10: 36-50.

Shad, H.H., J. Darvish and E. Rastegar Pouyani. 2016. Genetic variation in populations of field mouse Apodemus witherbyi (Thomas, 1902) (Rodentia: Muridae) in Iran inferred from mitochondrial Cytochrome $B$ gene sequences and geometric morphometrics. Acta Zool. Bulg. 68: 311-320.

Shahabi, S., J. Darvish, M. Aliabadian, O. Mirshamsi and Z. Mohammadi. 2011. Cranial and dental analysis of mouse-like hamsters of the genus Calomyscus (Rodentia: Calomyscidae) from plateau of Iran. Hystrix It. J. Mamm. 22: 311-323.

Shahabi, S., M. Aliabadian, J. Darvish and C.W. Kilpatrick. 2013a. Molecular phylogeny of brush-tailed mice of the genus Calomyscus (Rodentia: Calomyscidae) inferred from mitochondrial DNA sequences. Mammalia 77: 425-431.

Shahabi, S., J. Darvish and M. Aliabadian. 2013b. Phylogeny of genus Calomyscus (Rodentia: Calomyscidae) from Iranian plateau, inferred from mitochondrial $\mathrm{CO} 1$ gene. Anim. Res. J. (Iran. Biol. J.) 26: 163-170. (In Persian with English abstract).

Siahsarvie, R., R. Rajabi and J. Darvish. 2005. New Records of the Afghan Vole, Blanfordimys afghanus (Rodentia: Arvicolinae) from North-East of Khorassan, Iran. Iran. J. Anim. Biosystemat. 1: 29-44.

Siahsarvie, R. and J. Darvish. 2007. New records of naked-footed gerbil Gerbillus nanus and pygmy gerbil Gerbillus cfr. henleyi (Rodentia: Muridae) from Iran. Iran. J. Anim. Biosystemat. 3: 43-48.

Siahsarvie, R. and J. Darvish. 2008. Geometric morphometric analysis of Iranian wood mice of the genus Apodemus (Rodentia, Muridae). Mammalia 72: 109-115.

Siahsarvie, R., J.-C. Auffray, J. Darvish, H. Rajabi-Maham, H.-T. Yu, S. Agret, F. Bonhomme and J. Claude. 2012. Patterns of morphological evolution in the mandible of the house mouse Mus musculus (Rodentia: Muridae). Biol. J. Linn. Soc. 105: 635-647.

Siahsarvie, R., J. Darvish and A. Sarafrazi. 2013. Geometric morphometric comparison of the mandibles of three species of vole of the genus Microtus (Rodentia: Arvicolinae) from northern Iran. Zool. Middle East 43: 21-29.

Tarahomi, M. and J. Darvish. 1999. Recognition of contact zone between two species of vole (Ellobius talpinus and Ellobius fuscocapillus) in the north foot of Hezarmasjed. Iran. J. Biol. 8: 1-4 (in Persian).
Tarahomi, M., M. Karami, J. Darvish, M. Malek and M. Jangjoo. 2010. Geometric morphometric comparison of mandible and skull of five species of genus Allactaga (Rodentia: Dipodidae) from Iran. Iran. J. Anim. Biosystemat. 6: 61-69.

Taravati, S. and J. Darvish. 2010. GMTP: Geometric Morphometric Tools Package. Version 2.0 Beta (Program).

Taravati, S., J. Darvish and O. Mirshamsi. 2009. Geometric morphometric study of two species of the psammophilous genus Erodiontes (Coleoptera: Tenebrionidae) from the Lute desert, Central Iran. Iran. J. Anim. Biosystemat. 5: 81-89.

Yazdi, F.T., D. Adriaens and J. Darvish. 2012. Geographic pattern of cranial differentiation in the Asian Midday Jird Meriones meridianus (Rodentia: Muridae: Gerbillinae) and its taxonomic implications. J. Zool. Syst. Evol. Res. 50: 157-164.

Yazdi, F.T., A. Adriaens and J. Darvish. 2014a. Cranial phenotypic variation in Meriones crassus and M. libycus (Rodentia, Gerbillinae), and a morphological divergence in $M$. crassus from the Iranian Plateau and Mesopotamia (Western Zagros Mountains). Europ. J. Taxon. 88: 1-28.

Yazdi, F.T., P. Colangelo and D. Adriaens. 2014b. Testing a longstanding hypothesis on the relation between the auditory bulla size and environmental conditions: a case study in two jird species (Muridae: Meriones libycus and M. crassus). Mammalia 79: 185-200.

Yousefkhani, S.S.H., M. Aliabadian, E. Rastegar-Pouyani and J. Darvish. 2017a. Predicting the impact of climate change on the distribution pattern of Agamura persica (Dumeril, 1856) (Squamata: Gekkonidae) in Iran. Belg. J. Zool. 147: 137-142.

Yousefkhani, S.S.H., M. Aliabadian, E. Rastegar-Pouyani and J. Darvish. 2017b. Geographic variation in morphology of the genus Agamura Blanford, 1874 in Iran. Amphibia-Reptilia 38: 449-459.

Zarei, R., J. Darvish, H.R. Esmaeili and M. Tarahomi. 2010. A biosystematic survey of Shiraz (Central Part) rodents. Iran. J. Biol. 23: 573-583.

Zarei, B., J. Darvish, M. Aliabadian and F.Y. Moghaddam. 2013. Geometric morphometric analyses of four species of brushtailed mice, genus Calomyscus (Rodentia: Calomyscidae), from the Iranian Plateau. Iran. J. Anim. Biosystemat. 9: 73-81.

Corresponding author: Christiane Denys, Institut de Systématique et Evolution de la Biodiversité, MNHN, 57 Rue Cuvier, 75005 Paris, France, e-mail: christiane.denys@mnhn.fr

François Bonhomme: ISEM Génome, Populations, Interactions, Adaptation, UM2 - IFREMER - CNRS UMR 5171, Université de Montpellier II, Place E. Bataillon cc 63, F-34095 Montpellier Cedex 5, France

Boris Kryštufek: Vertebrate Department, Slovenian Museum of Natural History, Ljubljana, Slovenia

Marjan Mashkour and Jean Denis Vigne: UMR 7209 CNRS, Archéozoologie, Archéobotanique: Sociétés, Pratiques et Environnements, MNHN, 75005 Paris, France

Roohollah Siahsarvie: Rodents Group, Ferdowsi University, Mashhad, I.R. Iran 